\section{Association of Maternal Work with Adverse Perinatal Outcome}

\author{
Mostafa A. Arafa, DrPH ${ }^{1}$ \\ Taher Amine, $\mathrm{DrPH}^{2}$ \\ Moataz Abdel Fattah, DrPH ${ }^{3}$
}

\section{ABSTRACT}

Objective: To investigate the relationship between maternal work and pregnancy outcome.

Methods: Over a 4-month period from October 2004 through February 2005, 2,419 women were interviewed shortly after delivery in the three main public and Health Insurance hospitals in Alexandria, Egypt. Of these, 730 (30.2\%) were working and $1,689(69.8 \%)$ were not working prior to delivery. A detailed description of working status was analyzed, along with a risk profile which was compared between the two groups.

Results: There was no significant association between different work characteristics and perinatal outcomes except for that between working posture, stress and delivery of smallfor-gestational-age (SGA) babies. There was an excess rate of SGA and perinatal death among the non-working group, while preterm delivery was significantly increased among those who worked throughout the whole pregnancy. After adjusting for confounders, the risk of preterm delivery was no longer significant $(\mathrm{OR}=1.2,95 \% \mathrm{Cl}=0.96-1.7)$. On the other hand, working status had a beneficial effect on SGA and perinatal death $(O R=0.41$, $95 \% \mathrm{Cl}=0.26-0.64$ and $\mathrm{OR}=0.26,95 \% \mathrm{Cl}=0.14-0.48$, respectively).

Conclusion: These results cast doubt on the risk of adverse pregnancy outcome for women who work during pregnancy. Work per se does not constitute a health risk factor and may even have a positive social impact on pregnancy. Further research on this topic in our region is recommended.

MeSH terms: Maternal work; adverse pregnancy outcome; developing countries; strenuous work

La traduction du résumé se trouve à la fin de l'article.

1. Department of Epidemiology, High Institute of Public Health, Alexandria University, Alexandria, Egypt

2. Department of Occupational Health, High Institute of Public Health, Alexandria University

3. Department of Medical Biostatistics, Medical Research Institute, Alexandria University

Correspondence: Dr. Mostafa A. Arafa, Professor of Epidemiology, High Institute of Public Health Alexandria University, 165 El horreya Ave, Al Hadara, Alexandria, Egypt, E-mail: mostafaarafa@hotmail.com
T he potential impact of employment on pregnancy is an important issue that merits assessment, given the increasing numbers of women entering the labour force and continuing employment throughout pregnancy. Guidelines in some European countries and the United States suggest that pregnant women should avoid prolonged standing and heavy lifting in the workplace during the second and third trimesters of pregnancy. ${ }^{1,2}$ Much attention is paid by obstetricians to the diet and environment of the pregnant woman in prenatal care, but it is possible that her work also may affect pregnancy outcome. In the workplace, women may encounter specific hazards of radiation or chemicals. More widespread are the problems of fatigue and boredom, which need careful assessment in relation to the outcome of pregnancy. These factors should be measured more precisely, thus allowing the physician to advise pregnant women better about the safe duration of work. ${ }^{3}$ Physical exertion in the workplace during pregnancy may be predictive of adverse reproductive outcome. Many studies have suggested that strenuous physical activity, including in the workplace during pregnancy, is associated with reduced infant birthweight, shorter gestation period, intrauterine growth retardation, spontaneous abortion, and some congenital malformations. ${ }^{4-10}$ These types of associations, however, have not been observed in other studies. ${ }^{11-14}$ Moreover, only a few such studies have been conducted in developing countries. ${ }^{15-18}$

As the Egyptian population grows, the size of the labour force grows even faster with an increased participation of women in the workforce. Much of women's work in Egypt remains unrecognized, as informal activities, unpaid work, and activities for domestic consumption are not included. In accordance to the Population Census, which captures female work in formal activities only, the participation rate of females in the total labour force increased from $10 \%$ in 1986 to $12.9 \%$ in 2000 and to $15.4 \%$ in $2001 .{ }^{19,20}$ To the authors' knowledge after review of the literature, this work was the first undertaken in Egypt to investigate the association between maternal work and adverse perinatal outcomes.

\section{MATERIAL AND METHODS}

The data for the current study were collected from three public hospitals in the 
City of Alexandria, the second capital of Egypt: El-Shatby Maternity Hospital (the Main University Hospital) and Gamal Abdel-Nasser and Karmouz Hospitals (the Main Health Insurance Hospital). These hospitals provide services to the inhabitants of Alexandria and nearby governorates. The study approached all parturients who were delivering in the hospitals during the period October 2004 through February 2005. Women who agreed to participate were interviewed during their postpartum stay in the hospital. Those who left work during pregnancy (antenatal leave, $n=5$ ), were on child care leave $(n=13)$ or had multiple births $(\mathrm{n}=97)$ were excluded. Only three women refused to participate in the study. All participants were interviewed by trained interviewers using a pre-coded questionnaire that included the following data: current age, age at marriage, education, antenatal care, history of present and past conceptions, medical history and any other circumstances that could lead to adverse perinatal outcome (i.e., vaginal bleeding, premature rupture of the membrane, etc.). Weight was recorded during the third trimester, but height was not taken as it is not routinely measured for pregnant women. For those participants in the working category, work characteristics were studied in detail, including: type of job, posture during work, duration of work in years, working hours and rest days/week. Those who work for more than 50 hours/week and/or who do not receive rest days were considered to be suffering from occupational fatigue. ${ }^{21}$ Stress at work was assessed via a psychological job demand questionnaire using a four-point scale: $\leq 3$ not stressed, 4-6 mild stress, 7-9 moderate stress and 10-12 severe stress. ${ }^{22}$ Shortly after delivery, gestational age was assessed using the Ballard scoring system. ${ }^{23}$

\section{Perinatal outcome}

Three main perinatal outcomes were assessed: premature birth (delivery before the $37^{\text {th }}$ week of gestation), small for gestational age (SGA) (birthweight below the $10^{\text {th }}$ percentile for weight for a given gestational age according to Egyptian standard weight for age distribution), and perinatal death.

\section{Analysis}

The first part of the analysis was restricted to working women and looked at the
TABLE I

General Characteristics of Working and Non-working Women

\begin{tabular}{|c|c|c|c|c|c|c|}
\hline \multirow{2}{*}{ Age (vears) } & \multicolumn{2}{|c|}{$\begin{array}{c}\text { Non-working } \\
\text { Women } \\
(n=1689)\end{array}$} & \multicolumn{2}{|c|}{$\begin{array}{l}\text { Working } \\
\text { Women } \\
(\mathrm{n}=730)\end{array}$} & \multirow[b]{2}{*}{$\chi^{2}$} & \multirow[b]{2}{*}{$\mathbf{P}$} \\
\hline & No. & $\%$ & No. & $\%$ & & \\
\hline $\begin{array}{l}\text { Age (years) } \\
<20\end{array}$ & 119 & 7.0 & 12 & 16 & 94.19 & 0.000 \\
\hline $20-35$ & 1422 & 84.2 & 563 & 77.1 & & 0.000 \\
\hline$>35$ & 148 & 8.8 & 155 & 21.3 & & \\
\hline \multicolumn{7}{|l|}{ Education } \\
\hline Illiterate & 900 & 53.3 & 81 & 11.1 & 688.1 & 0.000 \\
\hline Primary \& preparatory & 341 & 20.2 & 80 & 11.0 & & \\
\hline Secondary & 409 & 24.2 & 365 & 50.0 & & \\
\hline University & 39 & 2.3 & 204 & 27.9 & & \\
\hline \multicolumn{7}{|l|}{ Weight } \\
\hline$\leq 60 \mathrm{~kg}$ & 214 & 12.7 & 61 & 8.4 & 9.41 & 0.02 \\
\hline$>60 \mathrm{~kg}$ & 1475 & 87.3 & 669 & 91.6 & & \\
\hline History of abortion & 282 & 16.7 & 154 & 21.1 & 6.67 & 0.01 \\
\hline Previous perinatal death (yes) & 95 & 5.6 & 52 & 7.1 & 2.0 & 0.157 \\
\hline Previous preterm/LBW (yes) & 105 & 6.2 & 58 & 7.9 & 2.42 & 0.11 \\
\hline Bleeding in the current pregnancy (yes) & ) 138 & 8.2 & 74 & 10.1 & 2.46 & 0.11 \\
\hline \multicolumn{7}{|l|}{ Parity } \\
\hline 1 & 686 & 40.6 & 297 & 40.7 & 10.44 & 0.005 \\
\hline 2 & 417 & 24.7 & 220 & 30.1 & & \\
\hline$\geq 3$ & 586 & 34.7 & 213 & 29.2 & & \\
\hline \multicolumn{7}{|l|}{ Antenatal care } \\
\hline Yes & 1237 & 73.2 & 671 & 91.9 & 106.7 & 0.00 \\
\hline No & 452 & 26.8 & 59 & 8.1 & & \\
\hline
\end{tabular}

nature of their employment and its association to perinatal outcomes. The three outcomes were then compared to non-working women (housewives). A series of logistic regression analyses were performed to adjust for potential confounders; three models were created, one for each perinatal outcome. The dependent variables were the adverse outcome versus the outcome of normal births. Mother's working status was introduced first as a single independent predictor to evaluate its crude association with the outcomes, then all other factors that could result in adverse perinatal outcome were added in the model to adjust for their effect using forward stepwise method. Though cigarette smoking is an important confounding variable, it was not added in the model as there were only three women in the sample who smoked. In our culture, it is unusual to see women smoking in this social class.

\section{RESULTS}

Altogether, 2,534 women were approached in the study. After exclusion of those who did not meet the sample criteria and those who did not agree to participate, 2,419 women remained in the study and supplied complete data. Of these, 730 $(30.2 \%)$ were classified as working and $1,689(69.8 \%)$ as non-working. Most (82\%) were of middle social class. Table I illustrates the general characteristics (sociodemographic and obstetric) of both groups. Working mothers were older and had a higher level of education. The table also shows that rates for history of abortion, previous perinatal death, previous preterm or LBW delivery, and early bleeding in the current pregnancy were higher for working compared to non-working women, however history of abortion was the only significant variable. Housewives were more often found to be multiparous $(\geq 3)$. A significantly higher percentage of working women sought antenatal care compared to non-working women. The sample comprised different categories of employment: the lowest figure was unskilled labour $(8.4 \%)$, nearly one third of the sample was professionals $(31.1 \%)$, while clerical staff, paramedical staff, and skilled workers represented $25.5 \%, 18.2 \%$, and $16.7 \%$, respectively.

Of the sample of working women, $42.6 \%$ performed their work mostly in the sitting position, $39.5 \%$ stood, and $13.2 \%$ alternated between sitting and standing. Risky categories like squatting and carrying heavy objects each represented $0.5 \%$ of the sample, and the remaining percentages were in all combined categories. Of the different work characteristics, only stress and posture were found to be significantly associated with delivery of small babies $\left(\chi^{2}=18.95, \mathrm{p}=0.002\right.$ and $\chi^{2}=$ $9.68, \mathrm{p}=0.007$, respectively). There was an excess rate of adverse outcomes delivery among working women with fixed daytime work and no reported fatigue. 
TABLE II

Distribution of Adverse Outcomes According to Some Work Characteristics

\begin{tabular}{|c|c|c|c|c|c|c|c|c|c|c|c|c|c|c|c|}
\hline \multirow{3}{*}{$\begin{array}{l}\text { Work } \\
\text { Characteristics }\end{array}$} & \multicolumn{5}{|c|}{ Preterm } & \multicolumn{5}{|c|}{ SGA } & \multicolumn{5}{|c|}{ Perinatal Death } \\
\hline & \multicolumn{2}{|c|}{ Yes $(n=129)$} & \multicolumn{2}{|c|}{ No $(n=601)$} & \multirow[t]{2}{*}{$\chi^{2}$} & \multicolumn{2}{|c|}{ Yes $(n=29)$} & \multicolumn{2}{|c|}{ No $(n=701)$} & \multirow[t]{2}{*}{$\chi^{2}$} & \multicolumn{2}{|c|}{ Yes $(n=16)$} & \multicolumn{2}{|c|}{ No $(n=714)$} & \multirow[t]{2}{*}{$\chi^{2}$} \\
\hline & No. & $\%$ & No. & $\%$ & & No. & $\%$ & No. & $\%$ & & No. & $\%$ & No. & $\%$ & \\
\hline \multicolumn{16}{|l|}{ Work stress } \\
\hline Not stressed & 25 & 19.4 & 127 & 21.1 & 2.43 & 8 & 27.6 & 145 & 20.7 & 18.95 & 5 & 31.25 & 150 & 21.01 & 1.24 \\
\hline Mild & 76 & 58.9 & 312 & 51.9 & $p=0.48$ & 5 & 17.2 & 378 & 53.9 & $\mathrm{p}=0.002$ & 8 & 50 & 379 & 53.1 & $p=0.74$ \\
\hline Moderate & 27 & 20.9 & 152 & 25.3 & & 16 & 55.2 & 168 & 23.96 & & 3 & 18.75 & 175 & 24.5 & \\
\hline Severe & 1 & 0.8 & 10 & 1.7 & & 0 & 0 & 10 & 1.4 & & 0 & 0 & 10 & 1.4 & \\
\hline \multicolumn{16}{|l|}{ Fatigue } \\
\hline Yes & 12 & 9.3 & 36 & 5.99 & 1.9 & 5 & 17.2 & 44 & 6.3 & 3.74 & 2 & 12.5 & 47 & 6.6 & $\mathrm{FET}=0.292$ \\
\hline No & 117 & 90.7 & 565 & 94.0 & $p=0.168$ & 24 & 82.8 & 657 & 93.7 & $p=0.053$ & 14 & 87.5 & 667 & 93.4 & \\
\hline \multicolumn{16}{|c|}{ Working schedule } \\
\hline Morning & 106 & 82.2 & 504 & 83.9 & 0.22 & 21 & 72.4 & 587 & 83.7 & 2.75 & 13 & 81.25 & 597 & 83.6 & $\mathrm{FET}=0.504$ \\
\hline Shifts & 23 & 17.8 & 97 & 16.1 & $p=0.63$ & 8 & 27.6 & 114 & 16.3 & $p=0.10$ & 3 & 18.75 & 117 & 16.4 & \\
\hline \multicolumn{16}{|l|}{ Posture } \\
\hline Sitting & 55 & 42.6 & 256 & 42.6 & 0.02 & 18 & 62.1 & 296 & 42.2 & 9.68 & 10 & 62.5 & 302 & 42.3 & 4.96 \\
\hline Standing & 52 & 40.3 & 236 & 39.3 & $p=0.99$ & 3 & 10.3 & 281 & 40.1 & $\mathrm{p}=0.007$ & 2 & 12.5 & 286 & 40.1 & $p=0.08$ \\
\hline Alternating & 16 & 12.4 & 75 & 12.5 & & 5 & 17.2 & 92 & 13.1 & & 3 & 18.75 & 94 & 13.2 & \\
\hline
\end{tabular}

TABLE III

Distribution of Adverse Perinatal Outcomes with Working Status

\begin{tabular}{|c|c|c|c|c|c|c|}
\hline \multirow[t]{2}{*}{$\begin{array}{l}\text { Perinatal } \\
\text { Outcome }\end{array}$} & \multicolumn{2}{|c|}{$\begin{array}{c}\text { Non-working } \\
\text { Women }(n=1689)\end{array}$} & \multicolumn{2}{|c|}{$\begin{array}{c}\text { Working } \\
\text { Women }(n=730)\end{array}$} & \multicolumn{2}{|c|}{ Significance } \\
\hline & No. & $\%$ & No. & $\%$ & $\chi^{2}$ & $\mathbf{P}$ \\
\hline Preterm & 233 & 13.8 & 129 & 17.7 & 6.01 & 0.01 \\
\hline SGA & 209 & 12.4 & 29 & 4.0 & 40.55 & 0.00 \\
\hline Prenatal death & 82 & 4.9 & 16 & 2.2 & 9.32 & 0.02 \\
\hline
\end{tabular}

TABLE IV

Crude and Adjusted OR for Working Status with Regard to the Three Outcomes

$\begin{array}{ll}\text { Model 1 } & \text { Crude OR (95\% CI) } \\ \text { Preterm } & 1.4(1.06-1.69) \\ \text { SGA } & 0.29(0.19-0.43) \\ \text { Perinatal death } & 0.43(0.25-0.75) \\ & \\ \text { Model 2 } & \text { Adjusted OR (95\% CI) } \\ \text { Preterm } & 1.2(0.96-1.7) \\ \text { SGA } & 0.41(0.26-0.64) \\ \text { Perinatal death } & 0.26(0.14-0.48)\end{array}$

Variables added in the second model were: age, educational level, parity, previous perinatal death, previous abortion, previous preterm, and history of present conception (antenatal care, toxaemia of pregnancy, anemia, uterine bleeding, and premature rupture of the membrane).

Preterm delivery and perinatal death were encountered more often in women with mild work stress and who work in a sitting position, however the difference was not significant (Table II). It can be concluded from Table III that the percentages of SGA and perinatal death were significantly lower for working women $(4.0 \%$ and $2.2 \%$ in working mothers vs. $12.4 \%$ and $4.9 \%$ in non-working mothers, respectively), in contrast to preterm delivery where the risk was higher. The crude association between working status and the three outcomes (first model) was significantly higher for SGA and perinatal death especially. There was an increased risk of prematurity $(\mathrm{OR}=1.4,95 \% \mathrm{CI}=1.06-1.69)$ in contrast to SGA and perinatal death where the risk was significantly decreased $(\mathrm{OR}=$ 0.29 and $0.43,95 \% \mathrm{CI}=0.19-0.43$ and 0.25-0.75, respectively). The significant association between working status and prematurity was lost after taking into consideration the effect of other predisposing variables which were added to the second model $(\mathrm{OR}=1.2,95 \% \mathrm{CI}=0.96-1.7)$. On the other hand, the risk of working status on SGA and perinatal death remains significantly decreased in the second model $(\mathrm{OR}=0.41$ and $0.26,95 \% \mathrm{CI}=$ 0.26-0.64 and 0.14-0.48, respectively) (Table IV).

\section{DISCUSSION}

One of the most dramatic structural changes in Egypt is the increased participation of women in the paid labour force. Pregnant women in the developing world are increasingly involved in paid employment in addition to their household responsibilities. The resulting heavy workload might have an effect on the woman and her unborn child.
Several studies have examined the association between working characteristics and pregnancy outcome and indicated that long hours or irregular job hours, shift work, long periods of standing, high-stress work and certain postures were associated with adverse pregnancy outcomes. ${ }^{17,24-31}$ Mozurkewich et al. ${ }^{32}$ conducted a meta analysis to evaluate the association between working condition and adverse pregnancy outcomes, and concluded that specific working conditions may significantly increase a woman's risk of adverse pregnancy outcomes. However, none of these studies was conducted in a developing country like Egypt. Moreover, such associations have not been determined to be risk factors in other studies. ${ }^{33-35}$ The results of the current study indicated that only posture and stressed work had a significant association with delivery of small-for-date babies. Neither work fatigue (long working hours) nor shifts were significantly associated with increased risk of adverse pregnancy outcomes. The recent study conducted by Sydsjo et al. concluded that the continuous increase in infants' birthweight among working pregnant women did not correlate with increased rest periods. ${ }^{36}$

Most of the women in the present study were unable to determine the exact periods of standing and sitting while doing their work. In Egypt, in many workplaces and different work categories, working pregnant women - especially during the third trimester - are exempted from much workload and their periods of rest during work are increased. This in turn tends to diminish physical exertion during work. In addition, they are performing their work mostly sitting or alternating sitting with standing position, especially in the professional 
categories like teachers and clerical staff. Another limitation of the study is that we could not measure directly the physical exertion at work and depended mainly on evaluating the number of working hours. Furthermore, not all physical strain is equal; it is highly probable that housewives are as physically active as women who work, particularly women working in office jobs.

Comparing working and non-working status in relation to pregnancy outcomes revealed that working women had significantly lower rates of SGA and perinatal death than non-working women. There was an increased risk of preterm delivery for working women, which lost its significance after adjusting for other potential confounders. On the other hand, the risk of SGA and perinatal death was significantly decreased for the working group in its crude and adjusted association. In agreement with the findings in the current study, Saurel-Cubizolles et al. ${ }^{37}$ and Henriksen et al. ${ }^{38}$ found no evidence that work per se had any detrimental or beneficial effect on the risk of preterm delivery. Earlier studies ${ }^{39,40}$ indicated that working to term in the absence of contraindications did not impose any added risk to mother or infant. In the context of our findings, other researchers ${ }^{41,42}$ reached the conclusion that no significant difference between employed women and housewives was observed in their physical health or pregnancy outcome, and virtually all the indices of outcomes were slightly more favourable for the housewives.

In conclusion, the relationship between working status and pregnancy outcome could not be explained only by the women's demographic, social or personal characteristics; employment in itself places the woman within an integrated social network, allowing her to receive substantial support, which is beneficial during pregnancy. In addition, working women have more access to insured antenatal care, which increases their chances of better quality care and early detection of risk. An important issue that should be addressed in future research is whether there are any specific occupational groups that are at increased risk, for instance women who are facing very stressful jobs, both physically and psychologically, without social support and self-esteem. The present work is con- sidered a first step to understanding the main effects of work during pregnancy. The findings suggest that work per se has no serious effect on the woman or on her fetus and that healthy women without an adverse obstetric or medical history can safely continue in employment during pregnancy.

\section{REFERENCES}

1. Henriksen TB, Hedegaard M, Secher NJ, Wilcox AJ. Standing at work and preterm delivery. $\mathrm{Br} \mathrm{J}$ Obstet Gynecol 1995;102(3):198-206

2. Seguin RE. Pregnancy and the working woman: A review. J Ark Med Soc 1998;95(3):115-18.

3. Chamberlain G. Effect of work during pregnancy. Obstet Gynecol 1985;65(5):747-50.

4. Berkowitz GS. Employment-related physical activity and pregnancy outcome. J Am Med Womens Assoc 1995;50(5):167-69.

5. Eskenazi B, Fenster L, Wight S, English P, Windham GC, Swan SH. Physical exertion as a risk factor for spontaneous abortion. Epidemiology 1994;5:6-13.

6. Hatch M, Ji B-T, Shu XO, Susser M. Do standing, lifting, climbing, or long hours have an effect on fetal growth? Epidemiology 1997;8:530-36.

7. Tan TC, Donnan SP, Chang AM. Employment, physical overactivity and adverse pregnancy outcomes-applicability of AMA guidelines in Chinese women. Asia Pac J Public Health 1998;2:22-27.

8. Barnes DL, Adair LS, Popkin BM. Women's physical activity and pregnancy outcome: A longitudinal analysis from the Philippines. Int $J$ Epidemiol 1999;20:162-72.

9. Ahlborg G. Physical work load and pregnancy outcome. J Occup Environ Med 1995;37:941-44.

10. Lin S, Gensburg L, Marshall EG, Roth GB, Dlugosz L. Effects of maternal work activity during pregnancy on infant malformations. J Occup Environ Med 1998;40:829-34.

11. Simpson JL. Are physical activity and employment related to preterm birth and low birth weight? Am J Obstet Gynecol 1993;168:1231-38.

12. Lokey EA, Tran ZV, Wells CL, Myers BC, Tran AC. Effects of physical exercise on pregnancy outcomes: A meta-analytic review. Med Sci Sports Exerc 1991;23:1234-39.

13. Irwin DE, Savitz DA, St Andre K, HertzPicciotto I. Study of occupational risk factors for pregnancy-induced hypertension among active duty enlisted Navy personnel. Am J Ind Med 1994:25:349-59.

14. Magann EF, Evans SF, Newnham JP. Employment, exertion, and pregnancy outcome: Assessment by kilocalories expended each day. Am J Obstet Gynecol 1996;175:182-87.

15. Tafari N, Naeye RL, Gobezie A. Effects of maternal undernutrition and heavy physical work during pregnancy on birth weight. BrJ Obstet Gynaecol 1980;87:222-26.

16. Clapp JF, Dichstein S. Endurance exercise and pregnancy outcome. Med Sci Sports Exerc 1994:16:556-62.

17. Tuntiserance $\mathrm{P}$, Geater A, Chongsuvivatwong V, Kor-Anantakul O. The effect of heavy maternal workload on fetal growth retardation and preterm delivery. J Occup Environ Med 1998;40:1013-20.

18. Florack EIM, Zielhuis GA, Rolland R. The influence of occupational physical activity on the menstrual cycle and fecundability. Epidemiology 1994;5:14-18

19. Central Agency for Public Mobilization and Statistics (CAPMAS), 2001. Economic participa- tion of women in Egypt. Available online at: http://www.aucegypt.edu/src/wsite1/Statistics/ Statistics2001.htm\#Female/male\%20gaps\%20in \%20basic\%20indicators (Accessed August 1, 2005).

20. Egyptian human development report, 2004 (UNDP, Egypt). Available online at: http://www.aucegypt.edu/src/wsite1/index.htm (Accessed August 1, 2005).

21. Working Time Regulations 1998. SI 1998 No.1833 - Health Aspects. Available online at: http://www.occhealth.co.uk/Working_time_regs. htm (Accessed March 1, 2005).

22. Elo AL. Assessment of mental stress factors at work. In: Zenz C, Occupational Medicine, Third edition. St. Louis, MO: Mosby, 1994;945-55.

23. Ballard JL, Khoury JC, Wedig K, Wang L, Eilers-Walsman BL, Lipp R. New Ballard score expanded to include extremely premature infants. J Pediatrics 1991;119(3):417-23.

24. Spinillo A, Capuzzo E, Baltaro F, Piazza G, Nicola S, Iasci A. The effect of work activity in pregnancy on the risk of fetal growth retardation. Acta Obstet Gynecol Scand 1996;75(6):531-36.

25. Escriba-Aguir V, Perez-Hoyos S, SaurelCubizolles MJ. Physical load and psychological demand at work during pregnancy and preterm births. Int Arch Occup Environ Health 2001;74(8):583-88.

26. Henriksen TB, Hedegaard M, Secher NJ. The relation between psychosocial job strain and preterm delivery and low birthweight for gestational age. Int J Epidemiol 1994;23(4):764-74

27. Hanke W, Kalinka J, Makowiec-Daboowska T, Sobala W. Heavy physical work during pregnancy - a risk factor for small-for-gestational-age babies in Poland. Am J Ind Med 1999;36(1):200-5.

28. Zhu JL, Hjollund NH, Olsen J. National Birth Cohort in Demark. Shift work, duration of pregnancy and birth weight: The National Birth Cohort in Denmark. Am J Obstet Gynecol 2004;191(1):285-91.

29. Brett KM, Strogatz DS, Savitz DA. Employment, job strain, and preterm delivery among women in North Carolina. Am J Public Health 1997;87(2):199-204

30. Henriksen TB, Hedegaard M, Secher NJ. Standing and walking at work and birthweight. Acta Obstet Gynecol Scand 1995:74(7):509-16.

31. Ceron-Mireles P, Harlow SD, Sanchez-Carrillo CI. The risk of prematurity and small for gestational age births in Mexico City: The effect of working conditions and antenatal leave. $A m J$ Public Health 1996;86(6):825-31.

32. Mozurkewich EL, Luke B, Avni M, Wolf FM. Working conditions and adverse pregnancy outcome: A meta analysis. Obstet Gynecol 2000;95(4):623-35.

33. Gazit-Nissim S, Sheiner E, Mazor M, ShohamVardi I. Examining the connection between physical exertion in pregnancy and premature birth. Harefauh 2000;138(60):444-48.

34. Hanke W, Saurel-Cubizolles MJ, Sobala W, Kalinka J. Employment status of pregnant women in Central Poland and the risk of preterm delivery and small-for-gestational-age infants. Eur J Public Health 2001;11(1):23-28.

35. Pompeii LA, Savitz DA, Evenson KR, Rogers B, Macmahon M. Physical exertion at work and the risk of preterm delivery and small-for-gestationalage birth. Obstet Gynecol 2005;106(6):1279-88.

36. Sydsjo A, Brynhildsen J, Selling KE, Josefsson A, Sydsjo E. Influence of rest during pregnancy on birth weight in working women. Obstet Gynecol 2006;107(5):991-96

37. Saurel-Cubizolles MJ, Zeitlin J, Lelong N, Papiernik E, Di Renzo GC, Breart G, et al. Employment, working conditions, and preterm birth: Results from the European Case Control Survey. I Epidemiol Community Health 2004;58(5):395-401 
38. Henriksen TB, Savitz DA, Hedegaard M, Secher NJ. Employment during pregnancy in relation to risk factors and pregnancy outcome. $\mathrm{Br} J$ Obstet Gynecol 1994;101(10):858-65.

39. Saurel-Cubizolles MJ, Subtil D, Kaminski M. Is preterm delivery still related to physical working condition during pregnancy? I Epidemiol Community Health 1991;45(1):29-34.

40. Mabury MC, Linn S, Monson RR, Wegman DH, Schoenbaum SC, Stubblefield PG, et al. Work and pregnancy. J Occup Med 1984;26(6):415-21.

41. Murphy JF, Dauncey M, Newcombe R, Garcia J, Elbourne D. Employment in pregnancy: Prevalence, maternal characteristics, and perinatal outcome. Lancet 1984;1(8387):1163-66

42. Hanke W, Kalinka J, Szymczak W. Socialoccupational risk factors for fetal growth retardation and preterm birth. Role of occupational and non-occupational work. Med Prev 1995;46(5):433-42.

Received: January 13, 2006

Accepted: September 14, 2006

\section{RESUME}

Objectif : Étudier la relation entre le travail pendant la grossesse et les résultats périnatals.

Méthode : Nous avons interviewé 2419 femmes peu de temps après leur accouchement dans les trois principaux hôpitaux publics et privés d'Alexandrie, en Egypte, sur une période de quatre mois. Parmi ces femmes parturientes, 730 (30,2 \%) avaient travaillé et 1689 (69,8\%) n'avaient pas travaillé pendant leur grossesse. Nous avons analysé des descriptions détaillées du travail effectué et comparé le profil de risques des deux groupes.

Résultats : Nous n'avons observé aucune association significative entre les diverses caractéristiques du travail et les résultats périnatals, exception faite d'un lien entre la posture au travail, la tension et I'accouchement d'un bébé petit pour son âge gestationnel (PAG). Les taux de PAG et de décès périnatal étaient plus élevés chez les femmes qui ne travaillaient pas, tandis que le taux d'accouchement prématuré augmentait considérablement chez les femmes ayant travaillé pendant toute la période de grossesse. En ajustant les taux pour tenir compte des facteurs de confusion, le risque d'accouchement prématuré n'était plus considérable ( $R C=1,2$, IC de $95 \%=0,96-1,7)$. D'autre part, le fait de travailler avait un effet bénéfique sur les taux de PAG et de décès périnatal ( $R C=0,41$, IC de $95 \%=0,26-0,64$ et $R C=0,26$, IC de $95 \%=0,14-0,48$, respectivement $)$.

Conclusion : Ces résultats mettent en doute l'élément hasardeux du travail pendant la grossesse puisque le travail en soi ne constitue pas un facteur de risque pour la santé, mais peut même avoir un impact social positif sur la grossesse, ce qui suggère qu'il faudrait pousser les recherches sur ce sujet dans notre région.

\section{PREVENT, PREPARE for and PROTECT YOURSELF from the next FLU PANDEMIC}

The Canadian Public Health Association (CPHA) and the Pandemic Health Alert Network are informing Canadians about the basic public health steps we can all take to help prevent the spread of infection, prepare to cope in an emergency, and protect our health during a flu pandemic.

Around the world, governments are gearing up for the next flu pandemic. Websites, fact sheets and checklists abound. However, the language they use and level of information they provide can be overwhelming and technical. To address this, CPHA and the Pandemic Health Alert Network have created a toolkit of practical, evidence-based information that is communicated in plain language.

This simple and practical toolkit provides Canadians with the information they need to protect themselves in a flu pandemic. The tools are easy to use, with common sense measures Canadians can put into practice in their daily lives.
These simple public health steps fall into three action areas:

1. PREVENT - basic public health habits that reduce the chance of catching and spreading the flu, such as proper hand washing;

2. PREPARE - easy-to-follow instructions on how to be prepared for a flu pandemic, or other emergency situation; and

3. PROTECT - crucial information on self-care during a flu pandemic.

The toolkit is designed to stimulate Canadians' interest to learn more and put that knowledge into action with simple measures that could stem the force of the next flu pandemic. The hope is that these steps will strengthen public resilience. That way we'll all be better prepared to cope in a flu pandemic, or other public health emergency.

The toolkit is available in English and French, online at www.pandemic.cpha.ca. 